Editorial Manager(tm) for Journal of Paleolimnology

Manuscript Draft

Manuscript Number: JOPL1782R1

Title: Vegetation changes in the southern Pyrenean flank during the last millennium in relation to climate and human activities: the Montcortès lacustrine record

Article Type: SI: Paleolimnology of IL

Keywords: Palynology; climatic change; human forcing; historical records; last millennium; Pyrenees

Corresponding Author: Dr Valentí Rull,

Corresponding Author's Institution: Botanic Institute of Barcelona

First Author: Valentí Rull

Order of Authors: Valentí Rull; Penélope González-Sampériz; Pablo Corella; Mario Morellón; Santiago Giralt

Abstract: This paper reports the vegetation changes of the last millennium, as deduced from palynological analysis of a sediment core from lake Montcortès, situated around $1000 \mathrm{~m}$ elevation in the southern pre-Pyrenean flank. The record begins in the Middle Ages ( AD 800) and ends around AD1920, with an average resolution of about 30 years. The reconstructed vegetation sequence is complex and shows the influence of both climate and human activities in the shaping of landscape. Prefeudal times were characterized by the presence of well-developed conifer forests, which were intensely burnt at the beginning of the feudalism (AD 1000) and were replaced by cereal (rye) and hemp cultivation, as well as meadows and pastures. In the 13th century, a relatively short warming likely corresponding to the Medieval Warm Period (MWP) was inferred by the presence of a low Mediterranean scrub community today restricted below $800 \mathrm{~m}$ elevation. This community disappeared during the Little Ice Age (LIA) cooling in the 15th century, coinciding with a decline in human activities around the lake. Forest recovery began around AD 1500, at the beginning of the Modern period, coinciding with wetter climates. However, forests retreated again during the 17 th century coinciding with a maximum in olive and hemp cultivation. This situation was reverted in post-Modern times (19th century), charactrized by an intense agricultural crisis and a significant decline of population that favored forest re-expansion. Correlations with the nearby Estanya lake, situated about $350 \mathrm{~m}$ below, provided a more regional picture. Besides some climatic forcing evident in both sequences, human activities seem to have the main drivers of landscape and vegetation change in the southern Pyrenean flank, in agreement with similar conclusions from other studies developed on high-mountain environments. 
Abstract This paper reports the vegetation changes of the last millennium, as deduced from palynological analysis of a sediment core from lake Montcortès, situated around $1000 \mathrm{~m}$ elevation in the southern pre-Pyrenean flank. The record begins in the Middle Ages ( AD 800) and ends around AD1920, with an average resolution of about 30 years. The reconstructed vegetation sequence is complex and shows the influence of both climate and human activities in the shaping of landscape. Pre-feudal times were characterized by the presence of well-developed conifer forests, which were intensely burnt at the beginning of the feudalism (AD 1000) and were replaced by cereal (rye) and hemp cultivation, as well as meadows and pastures. In the $13^{\text {th }}$ century, a relatively short warming likely corresponding to the Medieval Warm Period (MWP) was inferred by the presence of a low Mediterranean scrub community today restricted below $800 \mathrm{~m}$ elevation. This community disappeared during the Little Ice Age (LIA) cooling in the $15^{\text {th }}$ century, coinciding with a decline in human activities around the lake. Forest recovery began around $\mathrm{AD} 1500$, at the beginning of the Modern period, coinciding with wetter climates. However, forests retreated again during the $17^{\text {th }}$ century coinciding with a maximum in olive and hemp cultivation. This situation was reverted in postModern times ( $19^{\text {th }}$ century), charactrized by an intense agricultural crisis and a significant decline of population that favored forest re-expansion. Correlations with the nearby Estanya lake, situated about $350 \mathrm{~m}$ below, provided a more regional picture. Besides some climatic forcing evident in both sequences, human activities seem to have the main drivers of landscape and vegetation change in the southern Pyrenean flank, in agreement with similar conclusions from other studies developed on high-mountain environments. 


\title{
Vegetation changes in the southern Pyrenean flank during the last millennium in relation to climate and human activities: the Montcortès lacustrine record
}

\author{
Valentí Rull • Penélope González-Sampériz • Juan Pablo Corella \\ Mario Morellón · Santiago Giralt
}

V. Rull

Institut Botànic de Barcelona (CSIC-ICUB), Pg. del Migdia s/n, 08038 Barcelona, Spain.

e-mail: vrull@ibb.csic.es

P. González-Sampériz · J. P. Corella · M. Morellón

Instituto Pirenaico de Ecología (CSIC), Campus Aula Dei, Av. Montañana 1005, 50059 Zaragoza, Spain.

\section{S. Giralt}

Institut de Ciències de la Terra "Jaume Almera" (CSIC), Lluís Solé i Sabarís s/n, 08028 Barcelona, Spain 
Abstract This paper reports the vegetation changes of the last millennium, as deduced from palynological analysis of a sediment core from lake Montcortès, situated around $1000 \mathrm{~m}$ elevation in the southern pre-Pyrenean flank. The record begins in the Middle Ages ( AD 800) and ends around AD1920, with an average resolution of about 30 years. The reconstructed vegetation sequence is complex and shows the influence of both climate and human activities in the shaping of landscape. Pre-feudal times were characterized by the presence of well-developed conifer forests, which were intensely burnt at the beginning of the feudalism (AD 1000) and were replaced by cereal (rye) and hemp cultivation, as well as meadows and pastures. In the $13^{\text {th }}$ century, a relatively short warming likely corresponding to the Medieval Warm Period (MWP) was inferred by the presence of a low Mediterranean scrub community today restricted below $800 \mathrm{~m}$ elevation. This community disappeared during the Little Ice Age (LIA) cooling in the $15^{\text {th }}$ century, coinciding with a decline in human activities around the lake. Forest recovery began around $\mathrm{AD} 1500$, at the beginning of the Modern period, coinciding with wetter climates. However, forests retreated again during the $17^{\text {th }}$ century coinciding with a maximum in olive and hemp cultivation. This situation was reverted in postModern times ( $19^{\text {th }}$ century), charactrized by an intense agricultural crisis and a significant decline of population that favored forest re-expansion. Correlations with the nearby Estanya lake, situated about $350 \mathrm{~m}$ below, provided a more regional picture. Besides some climatic forcing evident in both sequences, human activities seem to have the main drivers of landscape and vegetation change in the southern Pyrenean flank, in agreement with similar conclusions from other studies developed on high-mountain environments.

\section{Keywords}

Palynology, climatic change, human forcing, historical records, last millennium, Pyrenees 


\section{Introduction}

The paleoecological study of mountain ecosystems is useful to document the effects of climate warming and to forecast its potential future consequences. A key issue in these type of surveys is the need for disentangling the relative influence of either natural climatic variations or human disturbance on the observed ecological shifts. A strategy is to compare the ecological changes occurred before the development of human societies (for example, during glacial or postglacial times) with those of the last millennia, when human activities have intensely transformed mountain landscapes and ecology. Another possibility is to develop multiproxy studies including independent proxies for climatic, ecological and anthropic processes and compare the results. Due to the available paleoecological information and its recent human history, the Pyrenean range is a suitable setting to use both approaches. On the one hand, the Pyrenees have been recognized as an important glacial refuge area from which European forests expanded during the post-glacial and Holocene warming (Jalut et al. 1992; Montserrat 1992; Brewer et al. 2002; Terhürne-Berson et al. 2004; González-Sampériz et al. 2004, 2005; Leroy and arpe 2007; Benito et al. 2008; Magri 2008). On the other hand, this range has a long history of around 7000 years of human settlement and landscape utilization (Marsan and Utrilla 1996; Galop 2001), with particular incidence in the last millennium (Esteban 2003; Miras et al 2007).

Long-term and historical ecological changes are often reconstructed by pollen analysis, as one of the best indicators of vegetation and climatic change (Birks and Birks 1980). In the Pyrenees, the extension and intensity with which the northern slope has been studied palynologically (reviews by Jalut et al. 1992; Reille and Lowe 1993 and Visset et al. 1996) have not been paralleled in the southern slope, where studies by Montserrat (1992), González-Sampériz et al. (2006) and Miras et al. (2007), among others, are worth mentioning. Studies covering the last millennium with some detail are also scarce but have recently increased (Galop 2001; Riera et al. 2004, 2006; Morellón et al. 2009b; Ejarque et al. 2009; Pèlachs et al. 2009a, b), and a first approach of the recent paleoecological history is starting to emerge. This paper reports the pollen analysis of the uppermost sediments from Lake Montcortès (1027 m elevation), which accounts for the vegetation changes occurred during the last millennium, and compares these results with previous reconstructions from the neighbor Lake Estanya (670 m 
elevation) during the same period (Riera et al. 2004, 2006; Morellón et al. 2009b).

Paleoclimatic trends are deduced from the multiproxy study (sedimentology, mineralogy, geochemistry and physical properties) of the laminated Montcortès sediments (Corella et al. this volume); whereas the potential influence of human activities in the ecological changes recorded is derived from more or less detailed historical records from the catchment area (Esteban 2003; Riera et al. 2004; Marugan and Rapalino 2005). Lake Montcortès sediments are an excellent target for highresolution studies with an accurate time control due to its relatively high sedimentation rates and the presence of varves (Corella et al. this volume). These are the ideal conditions to study the last millennia and try to disentangle the effects of natural environmental changes and human activities in the shaping of present-day landscapes.

\section{Study area}

Geographical setting and climate

Lake Montcortès is situated in the southern flank of the Central Pyrenees, in the Pallars region, at $42^{\circ} 19^{\prime} \mathrm{N}-0^{\circ} 59^{\prime} \mathrm{E}$ and $1027 \mathrm{~m}$ altitude (Fig. 1). This lake lies on karstic terrains characterized by the presence of Triassic limestones, marls and evaporites (Keuper and Muscheskalk facies), and Oligocene carbonatic conglomerates (Rosell 1994; Gutiérrez et al. 2008). The catchment is small and the lake is mainly fed mainly by groundwater, with intermittent small creeks and scattered springs. The main water outputs are due to evaporation and a small seasonal outlet at the north. The lake perimeter is roughly circular, with a diameter between 400 and $500 \mathrm{~m}$ and a maximum water depth of $30 \mathrm{~m}$ near the center (Camps et al. 1976; Modamio et al. 1988). The annual average temperature is $10.6{ }^{\circ} \mathrm{C}$, ranging from $1.9{ }^{\circ} \mathrm{C}$ in January to $20.3{ }^{\circ} \mathrm{C}$ in July. The total annual precipitation is $860 \mathrm{~mm}$, with March as the driest month (46.6 $\mathrm{mm}$ ) and May as the wettest one (99.2 $\mathrm{mm})$ (Corella et al. this volume).

\section{Vegetation}

The lake is around the altitudinal boundary between the Mediterranean lowlands and the Middle Montane belt, which in the Pyrenees is situated around 800-1000 m elevation, depending on local conditions (Vigo 2008). Three major forest formations coincide 
around the lake, as representative of this boundary condition (Fig. 2). The evergreen oak forests dominated by Quercus rotundifolia are representative of the Mediterranean lowlands, while the deciduous oak forests dominated by Quercus pubescens represent the Middle Montane belt, with higher total annual precipitation. The conifer forests of Pinus nigra subsp. salzmanii are mostly secondary and colonize, or eventually replace, the degraded deciduous oak forests (Folch 1981). Carreras et al. (2005-2006), using the CORINE system (CBM 1991), distinguished twelve vegetation types in the catchment (Fig. 2, Table 1). Around the lake, there is a belt of littoral vegetation dominated by Juncus, Scirpus, Phragmites, Typha and Sparganium (Camps et al. 1976).

Historical background

A summary of the main historical traits of the Pallars region is shown in Figure 3. The beginning of the Medieval period was marked by the defeat of the Roman Empire by the Visigoths (around AD 400), who dominated until the early $8^{\text {th }}$ century. The region was then under the dominance of the Muslims until about AD 800, when the Carolingians established. The last millennium has been subdivided into three main periods (Esteban 2003; Marugan and Rapalino 2005): Medieval Ages ( $8^{\text {th }}$ to $15^{\text {th }}$ centuries), Modern Ages (16 $6^{\text {th }}$ to $18^{\text {th }}$ centuries) and Post-modern Ages $\left(19^{\text {th }}\right.$ century onwards). Until the $10^{\text {th }}$ century, the southern Pyrenean flank was a poor and overpopulated region, due to the pressure of the northward Muslim expansion. The land was subdivided into small properties ruled by autonomous landholders. Forest clearance by fire was a common practice to prepare the terrains for shifting cultivation, the main economic activity at the time. After AD 1000, the individual properties were confiscated by the nobility and the church, thus determining the establishment of the feudal system, which endured until the end of the Middle Ages. Fire and shifting cultivation were replaced by a more permanent land exploitation system. The increase in cattle, mainly sheep, leaded to deforestation and the development of meadows and pastures. The more common crops were cereals (wheat, barley and oats), olive and vine. The last two, however, were restricted to the southern lowlands (less than about $1000 \mathrm{~m}$ elevation), due to climatic constraints. Towards the end of the Medieval period, a significant depopulation of the Pallars region was caused by internal wars, disease epidemics and the Little Ice Age cooling (Marugan and Oliver 2005). 
The feudalism collapsed and was replaced by the monarchy around AD 1500

(Modern Ages). This determined the return to a private property system, but this time the land owners were rich families and an oligarchic system established. The Pallars region became a marquisate and was newly populated by immigrants from the north (presently France). Agriculture and cattle raising experienced a significant expansion and diversification. The development of extensive livestock practices and the common use of animals for agriculture purposes (such as plowing and fertilizing) were especially significant. Forests were exploited mainly for wood, other common activities were mining, hunting and fishing. At the end of the Modern period, the commerce began to be important (Bringué 2005).

The post-modern period began with the nascent capitalist society typical of the $19^{\text {th }}$ century, characterized by the centralization of the production system and the existence of a well-developed route system for commercial interchange. The Pallars region, however, remained isolated and self-sufficient subsistence economy prevailed during the $19^{\text {th }}$ cenury. At the beginning of the $20^{\text {th }}$ century, the general agricultural crisis caused a new significant depopulation in the region, but the development of an extensive hydroelectrical power program soon promoted a socio-economic revival. The Civil War (AD 1936-1939) interrupted again the modernization trend, but a second hydroelectric program and a new mining development, revitalized the economy. Between 1960 and 1980, the industrialization caused a global crisis manifested in the massive emigration from rural to urban areas. Today, the main economic activities of the Pallars region are tourism and related services (Farràs 2005).

\section{Material and methods}

In April 2004, four sediment cores were obtained in the deepest part (about $30 \mathrm{~m}$ water depth) of the Montcortés lake following a NW-SE transect using a Kullenberg corer and platform of the Limnological research Centre (LRC), University of Minnesota. All the cores were split, imaged and their physical properties measured with a Geotek (Corella et al. this volume). Core MON-04-1A-1K, $6.69 \mathrm{~m}$ long, was selected for palynological analysis and sampled every $10 \mathrm{~cm}$. In this paper, we report the results of the upper 3.60 $\mathrm{m}$, roughly corresponding to the last millennium. Chronology was taken from the agedepth model of Corella et al. (this volume), based on radiocarbon dating of 
macroremains and bulk sediment samples. The average resolution of this pollen record is around 33 years per sampling interval, ranging between about 14 and 59 years.

Pollen samples consisted of $\sim 3-5 \mathrm{~g}$ of sediment, which were processed with standard palynological methods, including $\mathrm{NaOH}, \mathrm{HCl}$ and $\mathrm{HF}$ digestions and density gradient centrifugation, without acetolysis (Bennett and Willis 2001). Two Lycopodium tablets (batch $\mathrm{n}^{\mathrm{o}} 483216 ; 18,583$ spores/tablet) were added to each sample before chemical processing. Residues were suspended in glycerine and slides were mounted with glycerine-jelly. Pollen and pteridohyte spores were identified and counted until diversity saturation (Rull 1987), obtaining total counts between 289 and 873 (average 427). Algae remains were also identified to the genus level and counted. Fungal spores and charcoal particles above $5 \mu \mathrm{m}$ were counted as a group. The percentage diagram was based on the pollen sum $(\Sigma \mathrm{P})$, which included all pollen types except those from aquatic plants (Cyperaceae, Cladium, Myriophyllum, Pinguicula, Potamogeton, Ranunculus, Typha/Sparganium-type and Utricularia), ranging from 266 to 866 (average 421 ) counts. Pollen and spore types below $0.1 \%$ of the $\Sigma \mathrm{P}$ were not represented, these are: Acer, Androsace, Asphodelus albus/ramosus-t, Centaurea, Convolvulus, Cornus, Cupressus, Draba-t, Echium, Gentiana, Geranium, Linum, Myriophyllum, Paronychia-t, Pedicularis, Pinguicula, Polygonum aviculare-t, Populus, Potamogeton, Prunus avium-t, Ranunculus, Rhamnus, Sideritis, Tilia, Utricularia, Valeriana, Huperzia, Isoëtes and Lycopodium cernuum. Zonation was performed using the Optimum Splitting by Information Content (OSIC) and the broken-stick methods (Bennett 1996), considering only pollen types. Pollen groups (Table 2) were defined according to the present-day vegetation types. Percentages for non-pollen palynolorphs or NPP (algae, fungi, etc.) were referred to pollen sum.

\section{Results and interpretation}

The pollen diagram is dominated alternatively by trees and herbs, while shrubs are relatively scarce (Fig. 4). Among trees, the more abundant are Pinus and Quercus (evergreen) followed by Olea, whereas the dominant herbs are Poaceae (others), Plantago, Cannabis-type and Artemisia. Cyperaceae dominate the aquatic assemblage, in which Typha/Sparganium is important only in the upper part. Fern spores are 
comparatively scarce, in general. Total pollen and charcoal particles have their maxima near the base. The dominant vegetation types are conifer forests at the beginning, meadows/pastures in the middle, and herbaceous crops at the end. Oak forests show a progressive increase towars the top, while ruderal plants and weeds decline from the base to the top (Fig. 5). The following pollen zones have been identified:

Zone M-1 (360-325 cm, 1172-1000 cal BP, AD 778-950, 4 samples, 45 years/sampling interval)

This zone is dominated by Pinus, followed by Quercus (evergreen) and Poaceae (others), which show a decreasing trend towards the top. On the contrary, Cannabistype, Artemisia and psilate monoletes increase in the same sense. These patterns coincide with an increment in charcoal concentration. Conifer forests are the dominant vegetation type (Figures 4 and 5). Meadows/pastures are important at the base but they decline around the middle, where herbaceous crops and ruderal/weeds start to increase. Pseudoschizaea has its maximum development and Botryococcus is poorly represented (Fig. 6). Fungi are also at maximum values and increasing. Among them, Glomus is well represented. The whole picture suggests an initial pine woodland landscape around AD 800, being progressively reduced by fires and replaced by crops and associated elements (ruderal plants and weeds). The abundance of Pseudoschizaea and the scarcity of planktonic algae is consistent with low lake levels or marshy environments, indicative of dry climates (Scott 1992; Carrión 2002, Carrión et al. 2004, 2007). The presence of Glomus has been interpreted in terms of increased soil erosion (Anderson et al. 1984, van Geel et al. 1989, 2003; Leroy et al. 2009), and associated to intensification of human activities in the basin (López-Sáez et al. 2009, Argant et al. 2006). It should be also noticed that Glomus is a genus of mycorrhizal fungi commonly associated to forest vegetation. Forest management experiments have shown that mycorrhizal colonization of roots in pine and oak forests is significantly greater if half of the forest is removed, as compared to uncut and clearcut treatments (Zhou et al. 1997). Therefore, a medium-impact clearance of Pinus forests is suggested for the time interval between ca $\mathrm{AD} 780$ and 940.

Zone M-2 (325-203 cm, 1000-834 cal BP, AD 950-1116, 12 samples, 14 years/sampling interval) 
A dramatic decline in conifer forests, due basically to Pinus, marks the beginning of this zone (Fig. 4). Oak forests (both evergreen and deciduous) and shrubs slightly increase. The dominance is now shared by meadows/pastures (mainly Poaceae and Plantago) and herbaceous crops (Cannabis-type). The first dominate in the middle of the zone, coinciding with a maximum of ruderals/weeds, while the second peak at the beginning and at the end. Cultivated trees (mostly Olea) start to increase in the middle of the zone. These shifts in the pollen assemblages occur at the same time than an abrupt increase in both pollen and charcoal concentration, which attain their respective maxima. This pollen zone is interpreted in terms of intense land use, mainly cereal cultivation alternating with grazing -as indicated by the increase of meadows and pastures- after an abrupt and severe reduction of conifer forests using fire. Among non-pollen palynomorphs (NPP), Pseudoschizaea and Glomus drastically decline, while Tetraedron shows a conspicuous peak coinciding with the main charcoal maximum (Figs. 4 and 6). The decline in Glomus is consistent with a strongly reduced cover of Pinus forests (Zhou et al. 1997). The charcoal peak at the beginning of the zone coincides with a peak in Cannabis-type and Secale, whereas the dramatic charcoal decrease occurred around $290 \mathrm{~cm}$ ( AD 1000) coincides with the increase of meadows/pastures and ruderal/weeds. This suggests that, at that time, the use of fire was linked to herbaceous cropping rather than to pastoralism. The Tetraedron peak would be indicative of lake fertilization due to increased nutrient releasing linked to higher organic-rich sediment input.

Zone M-3 (2203-112 cm, 834-494 cal BP, AD 1116-1456, 9 samples, 39 years/sampling interval)

Evegreen and deciduous forests do not show significant changes with respect to zone M-2. The main differences occur in the formerly dominant meadows/pastures and herbaceous crops, which start a maintained decreasing trend, and the low scrubs (Rosmarinus-type, Helianthemum, Hedysarum-type and Ephedra), which peak in the middle of the zone and decrease around $140 \mathrm{~cm}$ ( AD 1360). This increase in low scrubs occurs shortly after a secondary charcoal peak, which decreases in the middle of the zone and attain minimum values at the end, where cultivated trees (Olea) start to increase. Ruderal/weeds show a maximum around the middle of the zone, just after the 
low scrub peak and before the Olea maximum. Total pollen attains its minimal values in this zone. Today, the same low scrub taxonomic association that characterized this zone corresponds to the Rosmarinetalia officinalis order (27.C), a thermophilous community typical of Mediterranean calcareous lowland dry environments below 800 m elevation (de Bolós 2001). This association is absent today at Lake Montcortès elevations, which suggests an upper displacement of at least $200 \mathrm{~m}$ of this vegetation type due to a warming between about AD 1100 and 1350. The small charcoal peak at the beginning of the zone is not followed by an increase of any taxa associated to human activities and would therefore support the occurrence of drier climatic conditions, favorable for wild fires. In spite of the low or null fire incidence, Pinus forests did not recover and only evergreen oak forests and shrubs expanded, suggesting drier climates and/or an intensification of seasonality. The appearance of the salinity-tolerant sedge Cladium would also support drier climates favoring increased evaporation. Also noteworthy is the cessation of cereal and hemp cultivation, and the increase of olive crops, since about AD 1280.

Zone M-4 (112-72 cm, 494-337 cal BP, AD 1456-1613, 4 samples, 29 years/sampling interval)

The main changes in this zone are the sharp increase of conifer forests, which peak around the middle, and the equally abrupt decline of meadows/pastures and ruderal/weeds group (mostly Artemisia). Oak forests, especially the deciduous ones, and scrublands also increase. Among cultivated plants, Olea shows a slight decrease and cereals are nearly absent, whereas hemp is very low at the beginning, but starts to increase around the middle of the zone, after the Pinus peak. There is no significant change in charcoal influx, which is at low values. The general decline of all cultivated elements and others associated to human activities (ruderal/weeds, meadows/pastures) and the low charcoal values indicate the low human pressure between about AD 1480 and 1590, though hemp cultivation seems to restart around AD 1550. The increase in other elements, especially conifer forests and Quercus deciduous forests, together with the increase of Corylus and the abrupt Artemisia decline, suggest a moderate increase in moisture. Low scrubs are at minimum values, suggesting colder climates. 
Zone M-5 (72-20 cm, 337-117 cal BP, AD 1613-1833, 5 samples, 34 years/sampling interval)

This zone is characterized by the decline of almost all pollen groups, except for the spectacular increase of Cannabis-type, which largely dominates the assemblage. This coincides with the increase in charcoal and fungi spores (incuding Glomus). The whole picture indicates the reinitiation of human activities around the lake since about AD 1630. Fires slightly reactivated, affecting primarily conifer and oak forests, and cultivation was largely centered on hemp, while Olea maintained the importance attained since the end of zone M-3 (AD 1280). The increase of Typha/Sparganium and the disappearance of Cladium suggest changes in lake shore environments or water salinity, probably freshening.

Zone M-6 (20-5 cm, 117-29 cal BP, AD 1833-1921, 2 samples, 30 years/sampling interval)

This zone is characterized by a conspicuous reversal of both Pinus and Cannabis-type pollen curves, the other pollen types remaining similar to the former zone. This indicates that hemp cultivation sharply declined around AD 1860, and conifer forests reexpanded.

\section{Discussion}

Comparison with sedimentological and historical records

The multiproxy study of the same core analyzed here provided the depositional and environmental history of the lake catchment during the last 6000 years (Corella et al. this volume). The time interval recorded in this study was subdivided into three main sedimentological phases, represented by the lithological units IV, III and II.

Sedimentary facies indicate that the lake has been deep and meromictic during the last 1500 years. During the Medieval epoch, represented by the lithological unit IV (AD 690 to 1460 ), the lake had a high clastic input. This unit was subdivided into two subunits (IVa and IVb), with the boundary around AD 1000. Unit IVb is dominated by turbiditic Facies 4, reflecting events of high terrigenous input, while Unit IVa is characterized by 
the dominance of laminated Facies 1, indicating less sediment delivery to the lake and low bottom bioturbation. This sedimentological unit 4 includes embraces pollen zones M-1 to M-3, and coincides with the Medieval epoch. The boundary between sedimentological units IVb and IVa coincides with the end of the main charcoal peak (Fig. 4) and the disappearance of Pseudoschizaea (Fig. 6), indicators of forest fires and increased terrigenous inputs to the lake, respectively. According to the historical records, this date (AD 1000) is the end of the pre-feudal epoch, when the predominant land use was forest burning and shifting cultivation, and the beginning of the feudalism, characterized by a more controlled use of fire and a more or less permanent land exploitation (Marugan and Oliver 2005). The same historical records also report the onset of vineyard and olive cultivation around the same times. In the Lake Montcortès pollen diagram, the Olea pollen consistently appear at $310 \mathrm{~cm}$ (AD 970), but Vitis is absent in the whole sequence. A possible explanation is that, during that time, olive and vineyard were cultivated mainly in lowlands below $1000 \mathrm{~m}$ elevation for climatic reasons (Marugan and Oliver 2005), and Olea pollen was better dispersed upwards than Vitis. In support to this, a recent work in a nearby area has shown the high upward dispersal efficiency of Olea pollen, which has been found in significant percentages in surface samples from 800 to $>2600 \mathrm{~m}$ elevation, in spite of the absence of the parent plant along the whole transect (Cañellas-Boltà et al. 2009). Another apparent inconsistency between historical and pollen records is the high amount of hemp pollen in the diagram and the absence of any reference to its cultivation in the Pallars region since the Medieval Ages to the present (Esteban 2003; Marugan and Rapalino 2005). One possibility is that hemp cultivation was restricted to certain favorable areas and this is not commonly reflected in historical accounts. But it is also possible that these crops were not autochthonous and the lake was used for hemp retting, as it occurred in the neighbor Lake Estanya during the same epoch (Riera et al. 2004). However, this is not reported in the writings reviewed so far and more work is still needed in this respect. Among the cereals mentioned in written documents, the better represented in the pollen diagram are wheat (Triticum) and rye (Secale), but the Poaceae curve should include other types less characteristic to be identified with confidence.

Concerning forests, pine woodlands were drastically reduced by AD 950, during the pre-feudalism, and did not recover during the whole Medieval epoch, when the landscape was likely a mosaic of predominantly crops and pastures, with smaller 
pine/oak forest patches. This human induced vegetation change also coincides with an increase in total pollen concentration, and the dominance of turbidites in the sedimentary sequence indicating enhanced runoff and siliciclastic inputs to the lake (Corella et al. this volume). The dillution effect of higher sedimentation rates on pollen concentrations, often observed elsewhere (e.g. Leroy et al. 2009), was not recorded here. The maximum in pollen concentration corresponds to increases in herbaceous crops, meadows/pastures and ruderal/weeds, and could be explained by enhanced pollen production due to the intensification of human activities linked to these vegetation types.

The vegetation changes recorded until around $\mathrm{AD} 1100$ were mainly triggered by human activities thus potential paleoclimatic signals are likely obscured. Historical records indicate the existence of a phase of "favorable weather" during $10^{\text {th }}$ and $11^{\text {th }}$ centuries (Fig. 3) that favored the expansion of crops and pastures in river margins and wetlands (Esteban 2003; Marugan and Oliver 2005), which is coherent with the interpretation of pollen zone M-2 (Fig. 4). Clearer palynological indications of warming and aridity were found afterwards, between about AD 1100 and 1350, by the presence of low Mediterranean scrub communities in pollen zone M-3. Similar warmer and drier phases have been recorded during the Middle Ages in Estanya and other lakes from the Iberian Peninsula (Morellón et al. 2009a), coinciding with the so-called Medieval Warm Period (MWP) of the Northern Hemisphere (Seager et al. 2007; Mann et al. 2009). The Medieval period ended with a cooling, as deduced from the decrease of the thermophilous low scrubs around AD 1400 and its disappearance from the site around AD 1460 (Fig. 5). Between this date and the end of the $15^{\text {th }}$ century, the Pallars region was significantly depopulated due to local wars, black pest epidemics and climate cooling. This cooling is coeval with the onset of the Little Ice Age (LIA) (Mann et al. 2009), which in Europe was cool and wet phase, also recorded in Estanya and other lakes of the Iberian Peninsula (Morellón et al. 2009a). As a result, many villages disappeared and the population concentrated in larger, lowland towns (Marugan and Oliver 2005). This land abandonment is reflected in the pollen diagram in the decline of charcoal and herbaceous crops at the end of zone M-3. Curiously, Olea, a lowland element, increases at the same time, attaining its maximum values $(\sim 8 \%)$. It could be hypothesized that olive cultivation increased in lowlands as a result of the population increase. 
Lithological Unit III was deposited during the Modern Ages, between AD 1460 and 1770, and is characterized by the predominance of Facies 1, indicating deep meromictic lake conditions with high bioproductivity and carbonate precipitation, and reduced terrigenous inputs (Corella et al. this volume). This is consistent with the palynological interpretation of zone M-4, as a period of forest expansion (mainly pines), reduced human activity around the lake (low values of charcoal, and crop and ruderal elements), and decreased terrigenous inputs to the lake (low values of Pseudoschizaea and fungi spores in Figure 6). Climate was still cool and probably wet, as it was common during the LIA, a period characterised by moisture fluctuations, as it is shown in the nearby Estanya record (Morellón et al. 2009a). In this case, it is likely that climate was dominant with respect to human activities in the shaping of the Montcortès landscape. A similar situation has been observed in other regional sequences such as Taravilla lake (Moreno et al. 2008), when climate and not human action seems the main cause of hydrological, sedimentological and vegetation changes recorded. The expansion of pastures documented in historical records after the feudalism in the Pyrenees is not recorded in the Montcortès pollen diagram, suggesting that once more, it occurred primarily in lowlands. A slight increase in clastic inputs was recorded at $\mathrm{AD}$ 1660 , coinciding with the returning to a phase of forest clearance and farming, as suggested by the decline of forests and the increase of charcoal and hemp pollen.

A significant sedimentological shift occurred at AD 1770, close to the end of the Modern epoch (Fig. 3), when turbiditic sedimentation (Facies 4) appeared again and sedimentation rates increased and remained so until the top of the sequence (Unit II). This coincides with pollen zone M-5, when the maximum of hemp cultivation and/or retting is observed (Fig. 4) suggesting a strong human activity in the lake watershed. Historically, this phase corresponds to the pre-capitalist or pre-industrial period, when subsistence agriculture was dominant in the Pallars region due to its geographic isolation. In the lowlands, below Lake Montcortès, crops expanded, whereas in the mountains above the lake, cattle raising and forest exploitation were the dominant practices (Bringué 2005). This situation is clearly reflected in the pollen diagram by the reduction of trees (especially Pinus) and the increase of herbaceous crops at the end of zone M-5. Once more, the large amount of hemp pollen contrasts with the lack of documentary evidence on its cultivation or the use of the lake for retting. The large 
amounts of Cannabis pollen in zone M-5 would be considered to favor the second option, but further work is needed for a definite assessment. Pollen zone M-6 coincides with a crisis of the subsistence agriculture and the significant decline in population of the Pallars region, coeval with the general European agricultural crisis of the mid- $19^{\text {th }}$ century (Farràs 2005). Both climate (floods) and agriculture pests have been invoked to explain this phenomenon. Despite the low number of samples in pollen zone M-6, the decline of herbaceous crops and the forest recovery are evident (Figs. 5) and consistent with historical accounts.

Correlations with the Estanya records: vegetation and land use

Before comparing the two records, it should be realized that Lake Montcortès (LM) and Lake Estanya (LE) settings possess different environmental characteristics due to their different altitudes. LE is situated $\sim 50 \mathrm{~km} \mathrm{SW}$ of LM and $350 \mathrm{~m}$ elevation below it. Therefore, LM is in the boundary between the Mediterranean lowlands and the Middle Montane belt, within the Submediterranean bioclimatic domain; whereas LE is in the Mediterranean lowlands, around the transition between the Submediterranean and the Mediterranean bioclimatic regime (Morellón et al. 2009b; Corella et al. in press). The climate around LE is continental Mediterranean, with a mean annual temperature of 14 ${ }^{\circ} \mathrm{C}$, ranging from 4 (January) to $24{ }^{\circ} \mathrm{C}$ (July); and an average annual precipitation of 470 $\mathrm{mm}$, ranging from 18 (July) to $50 \mathrm{~mm}$ (October) (Morellón et al. 2009b). At present, the vegetation is a mosaic of shrublands (such as Buxus, Juniperus, and Pistacia), oak forests (Q. rotundifolia), pastures, and barley (Hordeum) crops. Littoral vegetation around the lake is dominated by Tamarix, Phragmites, Juncus, Typha and Scirpus (Avila et al. 1984). Two pollen records of the last millennium are available for this lake: one in the deepest part, at $20 \mathrm{~m}$ water depth (Morellón et al. 2009b) and another littoral, under $1.5 \mathrm{~m}$ water depth (Riera et al. 2004). The first covers the last 800 years, whereas the second accounts for the last two millennia, both with a similar average resolution of around 50 years per sampling interval. The main results of these studies and Lake Montcortès, in terms of vegetation and land use, are depicted in Fig. 7 for comparison.

There is an initial phase of apparently undisturbed woodland around both lakes. In Montcortès, these forests were dominated by Pinus while in Estanya, Quercus (both deciduous and evergreen) were more abundant, likely because its lower altitude. 
Subsequent deforestation took place also in both localities, as recorded by sudden treepollen declines and major charcoal peaks, but it occurred first at Estanya (around AD 900; Riera et al. 2004) than at Montcortès, where it was not completed until the end of the pre-feudal period, slightly before AD 1000 . Although dating errors could not be disregarded, this northward trend would be consistent with historical records that report a conspicuous migratory trend towards the mountains caused by the northward Muslim expansion (Marugan and Oliver 2005). In this context, it is worth noting that Muslims occupied the region around Estanya between around AD 720 and AD 1030, but they did not reach the Montcortès area (Riera et al. 2004; Esteban 2003). Major deforestations also coincide with the end of shifting cultivation and the beginning of a more or less permanent and extensive land exploitation, which marks the beginning of the feudal epoch. This is manifested in the development of cereal and hemp cultivation in both localities studied. As stated before, occasional Olea and Vitis crops are mentioned in written documents, thus the scarcity of the first and the absence of the second in the Montcortès diagram is interpreted in terms of inadequate altitude for their cultivation. In Estanya, Olea pollen is also very scarce at that time, suggesting wind transport from lower altitudes, but Vitis is already present, though in low quantities (Riera et al. 2004).

The warming recorded at Montcortès between AD 1100 and 1350, correlated with the MWP, is paralleled at Estanya by equally warmer and drier climates, manifested in the increase of thermophilic elements in the pollen diagrams (Riera et al. 2004; Morellón et al. 2009a). During this warm and dry episode, fire events reappear at both Montcortès, around AD 1100, and Estanya, between about AD 1250 and 1300 (Morellón et al. 2009a). The first was of medium intensity and is not linked to extensive deforestation, possibly related to pastoralism. The second fire event was deduced from a barren, charcoal-rich layer from the deeper Estanya core (Morellón et al. 2009a), which is absent in the shallow one (Riera et al. 2004), and coincides with a conspicuous forest clearance event. A possible explanation for this discrepancy is that water levels were probably lower during that time (which is consistent with warmer and drier climates) and the shallow coring site was exposed; so charcoal was not deposited in the littoral zone or was removed by erosion. During this phase, agricultural activities did not experience significant changes in the lake catchments, but a vineyard expansion around Estanya is worth mentioning (Morellón et al. 2009a). 
The LIA cooling initiated around AD 1350 in Montcortès was also identified in

Estanya, where several moisture fluctuations occurred until the $19^{\text {th }}$ century. Morellón et al. (2009a) suggested several humidity oscillations, while Riera et al. (2004) proposed the occurrence of a dry episode between about AD 1600 and AD 1750, and two humid phases before and after, respectively (Fig. 7). The LIA onset was characterized, in both lake records, by a decline of cultivated plants suggesting an agriculture depression. This coincides with the so called "low medieval crisis", characterized by intense depopulation and land abandonment (it is estimated that around one third of the population emigrated and concentrated in larger towns located to the southern lowlands [Marugan and Oliver 2005]) attributed to the combined effect of climate deterioration, a "black death" epidemic occurred in AD 1348, local wars, and probably the collapse of the feudal system (Fig. 3) (Esteban 2003; Marugan and Rapaino 2005). Despite this agricultural crisis, both Montcortès and Estanya records document a progressive increase of Olea pollen culminating around AD 1500, which is interpreted as an expansion of olive crops in the region (Riera et al. 2004; Morellón et al. 2009a). According to written documents, an expansion of olive and vineyard crops occurred during this time at the southern lowlands, so it is probable that most of the recorded Olea pollen was transported upslope to the lake catchments by wind (Cañellas-Boltà et al. 2009).

The end of feudalism and the beginning of the Modern epoch (AD 1500) is characterized in Montcortès by a forest recovery, also documented in Estanya, where a still cooler but wetter climate has been suggested (Riera et al. 2004). During the $16^{\text {th }}$ century, pollen records show some spatial heterogeneity concerning land use (Fig. 7). This probably due to the contrasting histories of lowlands (used mainly for agriculture) and highlands (mostly dedicated to pastures and cattle raising) since the beginning of the Modern epoch, characterized by land privatization (Bringue 2005). In the $17^{\text {th }}$ century, a dramatic increase of hemp pollen was recorded in Montcortès and in the Estanya shallow core, coinciding with a dry episode and another forest clearance event (Riera et al. 2004). As noted before, the lack of written documentation about hemp cultivation around Montcortès prevents to know if the Cannabis pollen peak may be due to cultivation and/or retting, or both. High amounts of hemp pollen (10-80\%) together with the presence of a suitable environment are considered to be indicative of retting (Mercuri et al. 2002). In Montcortès, the suitable environment is provided by the lake 
and the hemp pollen is around $40-60 \%$ at that time, which strongly suggests retting. Anyway, it seems that hemp industry was a predominant activity in the region at that time. However, the hemp peak was not recorded in the Estanya deeper core, where this pollen type is comparatively less abundant and does not experience significant changes in time (Morellón et al. 2009a). Sedimentological and taphonomical factors cannot be disregarded but more records are still needed for a satisfactory explanation. The postModern crisis of subsistence agriculture and the coeval forest recovery, were also documented in the three available pollen records.

\section{General conclusions and final remarks}

After a detailed comparison of the Montcortès and Estanya records for the last millennium, it seems clear that human activities have played a major role in vegetation change history and have been crucial for the shaping of southern Pyrenean landscapes (Ejarque et al. 2009; Pèlachs et al. 2009a, b). The more intense climatic shifts (i. e. the MWP and the LIA) are still recognizable through particular plant associations, as for example the low Mediterraean scrubs in Montcortès; however, minor oscillations are likely obscured by the consequences of human land use. This is especially true for moisture changes, as the appearance or disappearance of plant communities commonly used as humidity proxies -as for example forests- have been mainly determined by human activities rather than by climatic reasons. As it is well known, biological records usually need independent evidence to interpret them in terms of climatic or anthropic factors, avoiding circular reasoning (e.g. Leroy 2010). Fortunately, in the case of Montcortès and Estanya lakes, abundant independent evidence is available from both sedimentological and documentary perspectives, which greatly strengthens paleoecological interpretation. In this study, both lines of independent evidence have been used to try to disentangle the potential forcing factors behind the vegetation changes recorded by pollen analyses. In general, vegetation patterns in time and human land-use changes have shown a high degree of coincidence but climate-humanslandscape relationships are complex and there is still room for improvement in our interpretations. For example, climate has not only a direct influence of natural communities but also an indirect one by affecting human practices, thus modifying the anthropic element of change. It would be interesting to further investigate this aspect. Another interesting point, which is already in progress, is the detailed paleolimnological 
reconstruction using aquatic proxies combined with sedimentological and physicochemical evidence (Scussolini et al., in prep). Montcortès is especially suited for such studies because its annually laminated sediments (Corella et al. in press). Also, the comparison of pollen and aquatic remains records would be useful to know the magnitude and time lag of the response of the involved organisms to environmental changes and, in this way, to evaluate their potential usefulness as paleoclimatic indicators.

\section{Acknowledgements}

Financial support for this research was provided by the Spanish Ministry of Science and Technology, through the projects LIMNOCLIBER (REN200309130-C02-02), IBERLIMNO (CGL2005-20236-E/CLI), LIMNOCAL (CGL200613327-C04-01) and GRACCIE (CSD2007-00067). Additional funding was provided by the Diputación General de Aragón (grant PM073/2007) and the Aragonese Regional Government-CAJA INMACULADA which partially funded the microfacies analysis at GFZ (Potsdam) by means of one travel grant. Juan Pablo Corella and Mario Morellón were supported by a $\mathrm{PhD}$ contract paid by the CONAI+D (Aragonese Scientific Council for Research and Development). Two anonymous referees contributed to the improvement of the manuscript. 


\section{References}

Anderson RS, Homola RL, Davis RB, Jacobson GL (1984) Fossil remains of the mycorrhizal fungal Glomus fasciculatum complex in postglacial lake sediments from Maine. Can J Bot 62: 2325-2328

Argant J, López-Sáez JA, Binz P (2006) Exploring the ancient occupation of a high altitude site (Lake Lauzon, France): Comparison between pollen and non-pollen Palynomorphs. Rev Palaeobot Palynol 141: 151-163

Ávila A, Burrel JL, Domingo A, Fernández E, Godall J, Llopart M (1984) Limnología del Lago Grande de estanya (Huesca). Oecol Aquat 7: 3-24

Benito M, Sánchez de Dios R, Sainz H (2008) The evolution of the Pinus sylvestris L. area in the Iberian Peninsula from the last glacial maximum to 2100 under climate change. Holocene 18: 705-714

Bennett KD (1996) Determination of the number of zones in a biostratigraphical sequence. New Phytol 132: 155-170

Bennett KD, Willis KJ (2001) Pollen. In: Smol JP, Birks HJB, Last WM (eds), Tracking environmental change using lake sediments. Volume 3: terrestrial, algal, and siliceous indicators. Kluwer Acad Pub, Dordrecht, pp 5-32

Birks HJB, Birks HH (1980) Quaternary palaeoecology. E Arnold, London.

Brewer S, Cheddadi R, de Beaulieu JL, Reille M (2002) The spread of deciduous Quercus throughout Europe since the last glacial period. Forest Ecol Manag 156: 27-48

Bringué JM (2005) L'edat moderna. In: Marugan CM, Rapalino V (eds), Història del Pallars. Dels orígens als nostre dies. Pagès Editors, Lleida, pp 87-120

Camps J, Gonzalvo I, Güell J, López P, Tejero A, Toldrà X, Vallespinós F, Vicens M (1976) El lago de Montcortès, descripción de un ciclo annual. Oecol Aquat 2: 99-110 
Cañellas-Boltà N, Rull V, Vigo J, Mercadé A (2009) Modern pollen-vegetation relationships along an altitudinal transect of the Central Pyrenees (southwestern Europe). Holocene 19: 1185-1200

Carreras J, Vigo J, Ferré A (2005-2006) Manual dels hàbitats de Catalunya, vols I-VIII. Dep Medi Ambient i Habitatge, Generalitat de Catalunya, Barcelona, Spain

Carrión JS (2002) Patterns and processes of Late Quaternary environmental change in a montane region of southwestern Europe. Quat Sci Rev 21: 2047-2066

Carrión JS, Willis KJ, Sánchez-Gómez P (2004) Holocene forest history of the eastern plateaux in the Segura Mountains (Murcia, southeastern Spain). Rev Palaeobot Palynol 132: $219-236$

Carrión JS, Fuentes N, González-Sampériz P, Sánchez-Quirante L, Finlayson JC, Fernández S, Andrade A (2007) Holocene environmental change in a montane region of southern Europe with a long history of human settlement. Quat Sci Rev 26: 1455-1475

CBM (1991) CORINE Biotopes Manual. Habitats of the European Community. Comiss European Communities, Luxemburg

Corella JP, Moreno A, Morellón M, Rull V, Giralt S, Rico MT, Pérez A, and valeroGarcés B (in press) Climate and human impact on a meromictic lake during the last 6000 years. J Paleolimnol

de Bolòs O (2001) Vegetació dels Països Catalans. Aster, Barcelona, Spain de Bolòs O, Vigo J, Masalles RM, Ninot JM (1990) Flora manual dels Països Catalans. Pòrtic, Barcelona, Spain

Ejarque A, Julià R, Riera S, Palet JM, Orengo HA, Miras Y, Gascón C (2009) Tracing the history of highland human management in the eastern Pre-Pyrenees: an 
interdisciplinary palaeoenvironmental study at the Pradell fen, Spain. Holocene 19: $1241-1255$

Esteban A (2003) La humanización de las altas cuencas de la Garona y las Nogueras (4500 aC-1955 aC). Org Aut Parques Nacionales, Min Medio Ambiente, Madrid, Spain Farràs F (2005) El Pallars contemporani. In: Marugan CM, Rapalino V (eds), Història del Pallars. Dels orígens als nostre dies. Pagès Editors, Lleida, pp 121-144

Folch R (1981) La vegetació dels Països Catalans. Ketres, Barcelona, Spain Galop D (2001) La forêt, l'homme et le troupeau dans les Pyrénées. Géode-Laboratoire d'Ecologie Terrestre, Univ Toulouse-Le Mirail. Toulouse, France

González-Sampériz P, Valero-Garcés B, Carrión JS (2004) Was the Ebro valley a refugium for temperate trees? Anal Biol 26: 13-20

González-Sampériz P, Valero-Garcés BL, Carrión JS, Pena-Monne JL, García-Ruiz JM, Martí-Bono C (2005) Glacial and Lateglacial vegetation in northeastern Spain: New data and a review. Quat Int 140-141: 4-20

González-Sampériz P, Valero-Garcès BL, Moreno A, Jalut G, García-Ruiz JM, MartíBono C, Delgado-Huertas A, Navas A, Otto T, Deboub JJ (2006) Climate variability in the Spanish Pyrenees during the last 30,000 yr revealed by the El Portalet sequence. Quat Res 66: $38-52$

Gutiérrez F, Calahorra J, Cardona F, Ortí F, Durán J, Garay P (2008) Geological and environmental implications of the evaporite karst in Spain. Environ Geol 53: 951-965

Jalut G, Montserrat J, Fortugne M, Delibrias G, Vilaplana JM, Julià R (1992) Glacial to interglacial vegetation changes in the northern and southern Pyrenees: deglaciation, vegetation cover and chronology. Quat Sci Rev 11: 449-480 
Leroy SAG (2010) Pollen analysis of core DS7-1 (Dead Sea) showing intertwined effects of climatic change and human activities in the Late Holocene. J Archaeol Sci 37: 306-316

Leroy SAG, Arpe K (2007) Glacial refugia for summer-green trees in Europe and S-W Asia as proposed by ECHAM3 time-slice atmospheric model simulations. J Biogeogr 34: 2115-2128

Leroy SAG, Boyraz S, Gürbüz A (2009) High-resolution palynological analysis in Lake Sapanca as a tool to detect earthquakes on the North Anatolian Fault. Quat Sci Rev 28: 2616-2632

López-Sáez JA, López-Merino L, Mateo MA, Serrano O, Pérez-Díaz S, Serrano L (2009) Palaeoecological potential of the marine organic deposits of Posidonia oceanica: A case study in the NE Iberian Peninsula. Palaeogeogr Palaeoclimatol Palaeoecol 271: 215-224

Mann ME, Zhang Z, Rutherford S, Bradley RS, Hughes MK, Shindell D, Ammann C, Faluvegi G, Ni F (2009) Global signatures and dynamical origins of the Little Ice Age and Medieval Climate Anomaly. Science 326: 1256-1260

Magri D (2008) Patterns of post-glacial spread and the extent of glacial refugia of European beech (Fagus sylvatica). J Biogeogr 35: 450-463

Marsan G, Utrilla P (1996) L'implantation du Mégalithisme dans les passages des Pyrénées centrales. Comparaison des vallées d'Ossau et Tena-Canfranc. Pyrénées Préhistoriques. Arts et Sociétés. CTHS, Paris, pp 521-532

Marugan CM, Rapalino V (2005) Història del Pallars. Dels orígens als nostre dies. Pagès Editors, Lleida, Spain

Marugan CM, Oliver J (2005) El Pallars medieval. In: Marugan CM, Rapalino V (eds), Història del Pallars. Dels orígens als nostre dies. Pagès Editors, Lleida, pp 45-86 
Mercuri AM, Accorsi CA, Bandini Mazzanti M (2002) The long history of Cannabis and its cultivation by the Romans in central Italy, shown by pollen records from Lago Albano and Lago di Nemi. Veg Hist Archaeobot 11: 263-276

Miras Y, Ejarque A, Riera S, Palet JM, Orengo H, Euba I (2007) Dynamique Holocène de la végétation et occupation des Pyrénées andorranes depuis le Néolithique ancient, d'après l'analyse pollinique de la tourbière de Bosc dels Estanyons (2180 m, Vall de Madriu, Andorre). CR Paleovol 6: 291-300

Montserrat J (1992) Evolución glaciar y postglaciar del clima y la vegetación en la vertiente sur del Pirineo: estudio palinològico. Monog Instit Pirenaico Ecología 6, 145 $\mathrm{pp}$

Morellón M, Valero-Garcés B, González-Sampériz P, Vegas-Vilarrúbia T, Rubio E, Rieradevall M, Delgado-Huertas A, Mata P, Romero O, Engstrom DR, López-Vicente M, Navas A, Soto J (2009a) Climate changes and human activities recorded in the sediments of Lake Estanya (NE Spain) during the Medieval Warm Period and Little Ice Age. J Paleolimnol, doi: 10.1007/s10933-009-9346-3

Morellón M, Valero-Garcés B, Vegas-Vilarrúbia T, González-Sampériz P, Romero O, Delgado-Huertas A, Mata P, Moreno A, Rico M, Corella P (2009b) Lateglacial and Holocene palaeohydrology in the western Mediterranean region: The Lake Estanya record (NE Spain). Quat Sci Rev 28: 2582-2599

Moreno A, Valero-Garcés BL, González-Sampériz P, Rico M (2008) Flood response to rainfall variability during the last 2000 years inferred from the Taravilla Lake record (Central Iberian Range, Spain). J Paleolimnol 40: 943-961

Muenscher WC (1980) Weeds. Cornell University Press, Ithaca, USA

Pèlachs A, Pérez-Obiol R, Ninyerola M, Nadal J (2009a) Landscape dynamics of Abies and Fagus in the southern Pyrenees during the last 2200 years as a result of anthropogenic impacts. Rev Palaeobot Palynol 156: 337-349 
Pèlachs A, Nadal J, Soriano JM, Molina D, Cunill R (2009b) Changes in the Pyrenean woodlands as a result of the intensity of human exploitation: 2,000 years of metallurgy in Vallferrera, northeast Iberian Peninsula. Veg Hist Archaeobot, doi: 10.1007/s003344009-0218-6

Reille M, Lowe JJ (1993) A re-evaluation of the vegetation history of the eastern Pyrenees (France) from the end of the last glacial to the present. Quat Sci Rev 12: 47-77

Riera S, López-Sáez JA, Julià R (2006) Lake responses to historical land use changes in northern Spain: The contribution of non-pollen palynomorphs in a multiproxy study. Rev Palaeobot Palynol 141: 127-137

Riera S, Wansard G, Julià R (2004) 2000-year environmental history of a karstic lake in the Mediterranean Pre-Pyrenees: the Estanya lakes (Spain). Catena 55: 293-324

Rosell J (1994) Mapa Geológico de España y Memoria. Escala 1:50.000, Hoja de Tremp (252)

Rull V (1987) A note on pollen counting in paleoecology. Pollen Spores 29: 471-480

Scott L (1992) Environmental implications and origin of micrsocopic Pseudoschizaea Thiegart and Franz ex Potonié emend. in sediments. J Biogeogr 19: 349-354

Seager R, Graham N, Herweijer C, Gordon AL, Kushnir Y, Cook E (2007) Blueprints for Medieval hydroclimate. Quat Sci Rev 26: 2322-2336

Terhürne-Berson R, Litt Th, Cheddadi R (2004) The spread of Abies throughout Europe since the last glacial period. Veg Hist Archaeobot 13: 257-268

van Geel B, Coope GR, van der Hammen T (1989) Palaeoecology and stratigraphy of the Late glacial type section at Usselo (the Netherlands). Rev Palaeobot Palynol 60: 25129 
van Geel B, Buurman J, Brinkkemper O, Schelvis J, Aptroot A, van Reenen AG, Hakbijl T (2003) Environmental reconstruction of a Roman Period settlement site in Uitgeest (The Netherlands), with special reference to coprophilous Fungi. J Archaeol Sci 30: $873-883$

Vigo J (1983) El poblament vegetal de la Vall de Ribes. I. Generalitats i catàleg florístic. Acta Bot Barcino 35: 1-793

Vigo J (1996) El poblament vegetal de la Vall de Ribes. Les comunitats vegetals i el paisatge. Inst Cartogr Catalunya, Barcelona, Spain

Vigo J (2008) L'alta muntanya catalana: Flora i vegetació. Institut d'Estudis Catalans-C Excurs Catalunya, Barcelona, Spain

Visset L, Aubert S, Belet JM, David F, Fortugne M, Galop D, Jalut G, Janssen CR, Voeltzel D. and Huault MF (1996) France. In: Berglund BE, Birks HJB, RalskaJasiewiczowa M, Wright HE (eds), Palaeoecological events during the last 15,000 years. Wiley, Chichester, pp 575-646

Zhou M, Sharik TL, Jurgensen MF, Richter DL (1997) Ectomycorrhizal colonization of Quercus rubra seedlings in response to vegetation removals in oak and pine stands. Forest Ecol Manag 93: 91-99 


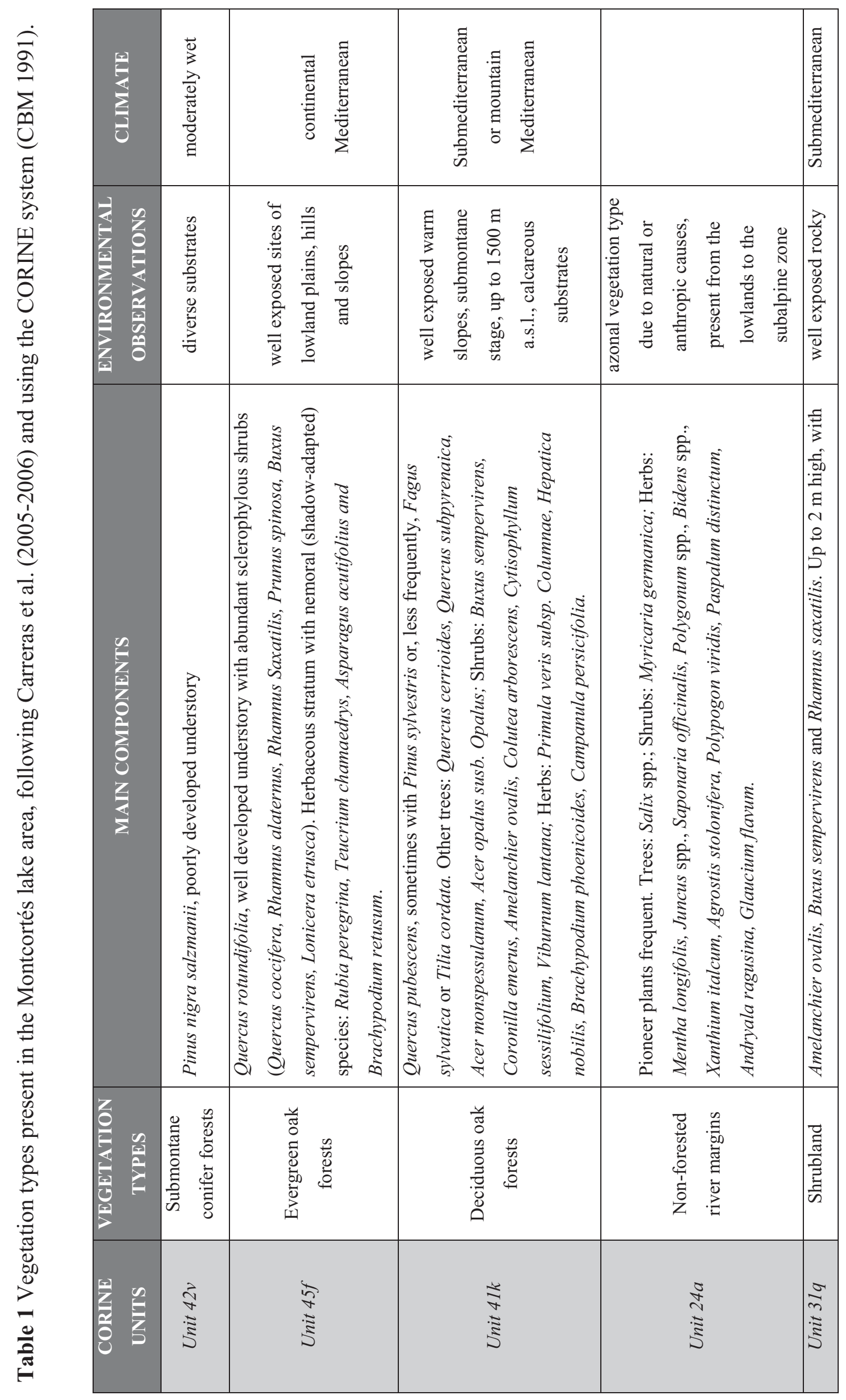




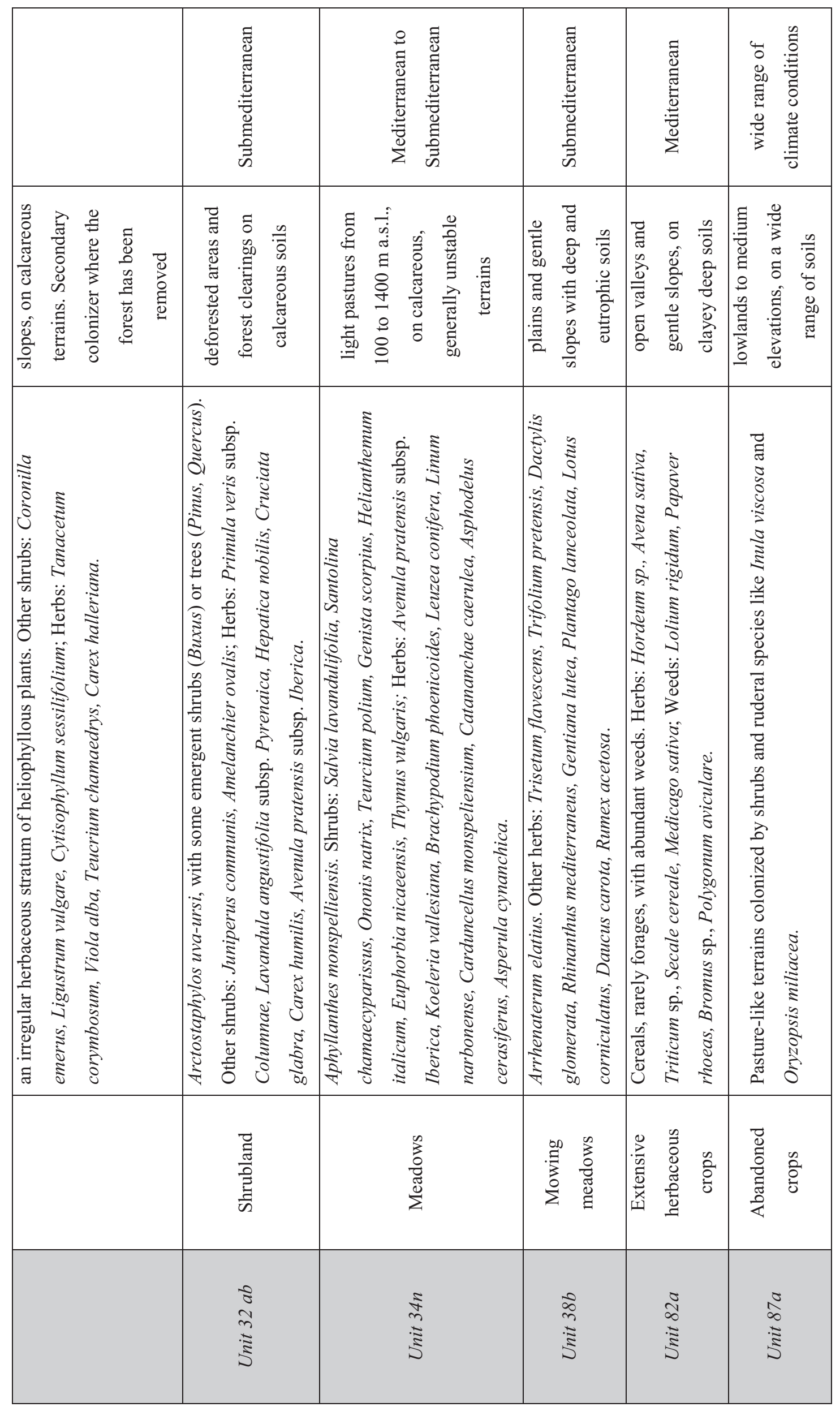




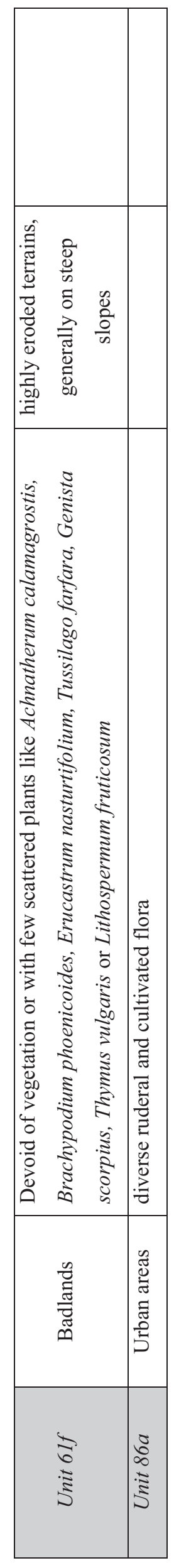

จิ

$\forall N m$ r n 


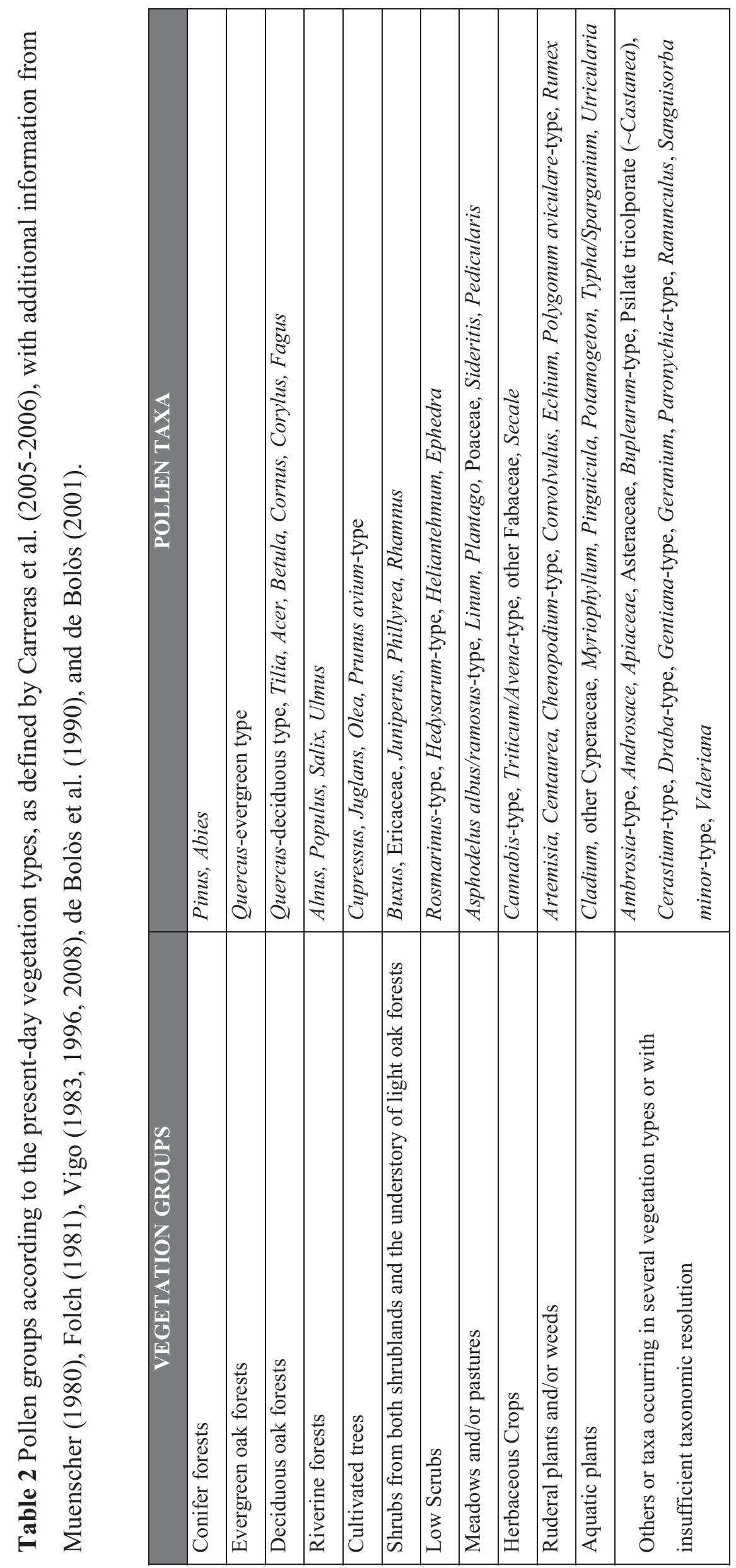




\section{Figure captions}

Figure 1. Location map of Lakes Montcortès and Estanya. The Pallars region is highlighted (grey area).

Figure 2. Vegetation map according to the classification of Carreras et al. (2005-2006), using the CORINE system (CBM 1991). L = Lake Montcortès.

Figure 3. Schematic account of the main historical periods and events in the Pallars region, especially those related to economic models and land use. Summary after Esteban (2003), Marugan and Oliver (2005), Bringué (2005), and Farràs (2005). LM = Lake Montcortès, $\mathrm{N}=$ North, $\mathrm{S}=$ South.

Figure 4. Percentage sporomorph diagram, including the total pollen and charcoal influx. Elements included in the pollen sum: CF - conifer forests, EOF - evergreen oak forests, DOF - deciduous oak forests, RF - riverine forests, $\mathrm{CT}$ - cultivated trees, $\mathrm{S}$ shrublands, MS - Low Mediterranean scrubs, M/P - meadows/pastures, HC herbaceous crops, R/W - ruderal/weeds. Elements outside the pollen sum: A - aquatic plants, F - ferns. Zonation was made using the Optimum Splitting by Information Content (OSIC) and the brocken stick methods (Bennett 1996). Solid lines indicate x10 exaggeration.

Figure 5. Percentage pollen diagram grouped by vegetation types, according to Carreras et al. (2005-2006), with additional information from Muenscher (1980), Folch (1981), Vigo (1983, 1996, 2008), de Bolòs et al. (1990), and de Bolòs (2001). The zonation is based on percentage diagram (Fig. 3).

Figure 6. Percentage diagram for non-pollen palynomorphs (NPP) with respect to the pollen sum. The scales of Tetraedron and Botryococcus have been reduced for more clarity. Solid lines indicate x10 exaggeration. Zonation as in Figure 3.

Figure 7. Interpretation of Montcortès pollen diagram and correlations with the existing Estanya records. LIA $=$ Little Ice Age, $\mathrm{MWP}=$ Medieval Warm Period. 


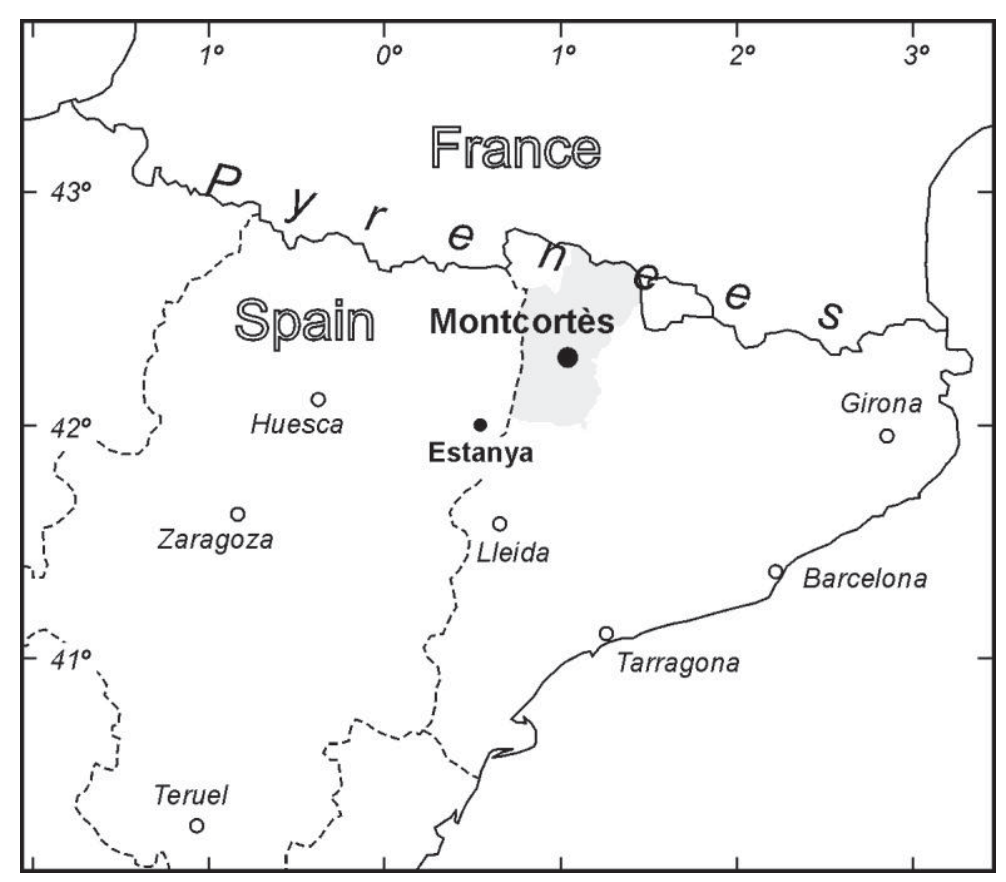

Figure 1

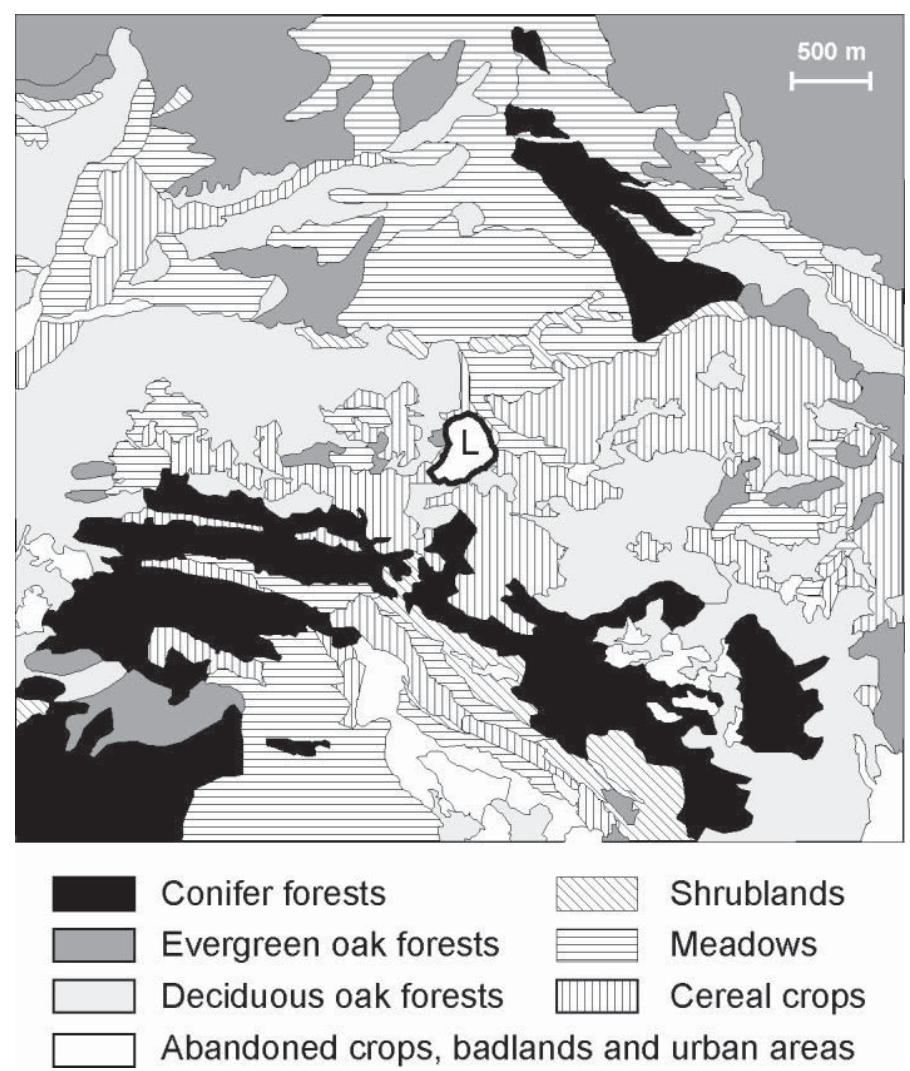

Figure 2 


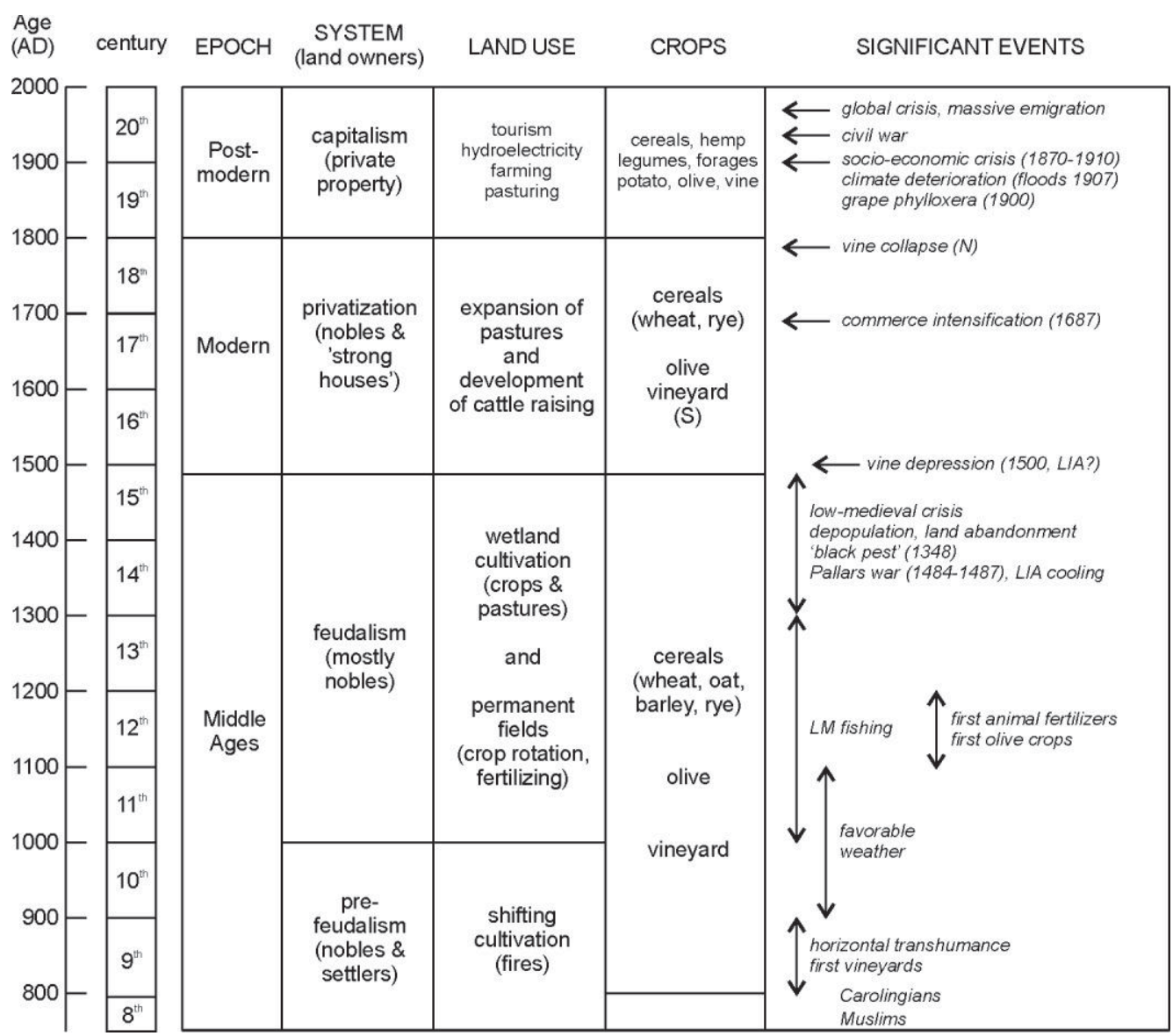

Figure 3 


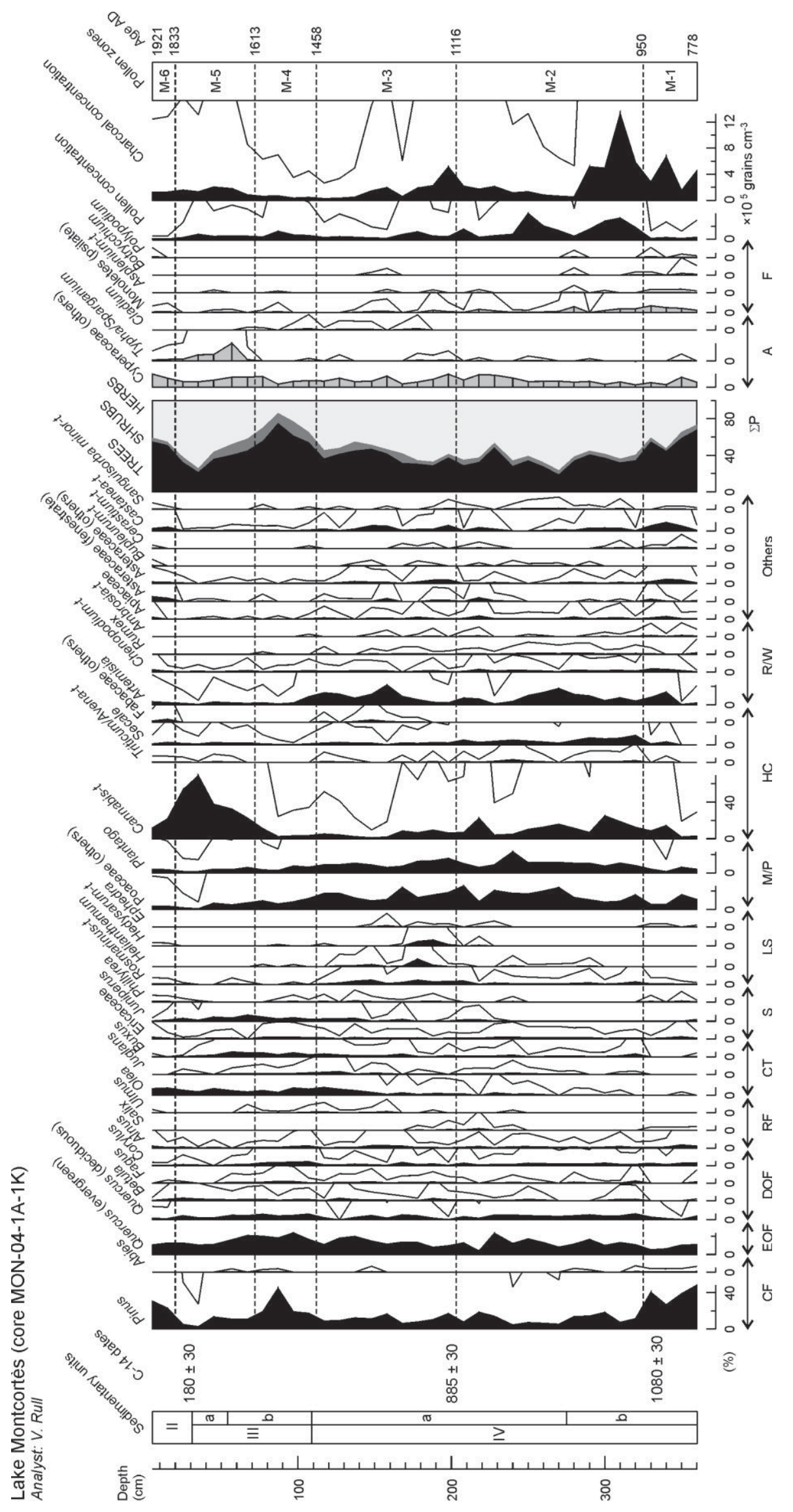

Figure 4 
Lake Montcortès (core MON-04-1A-1K) Analyst: V. Rull

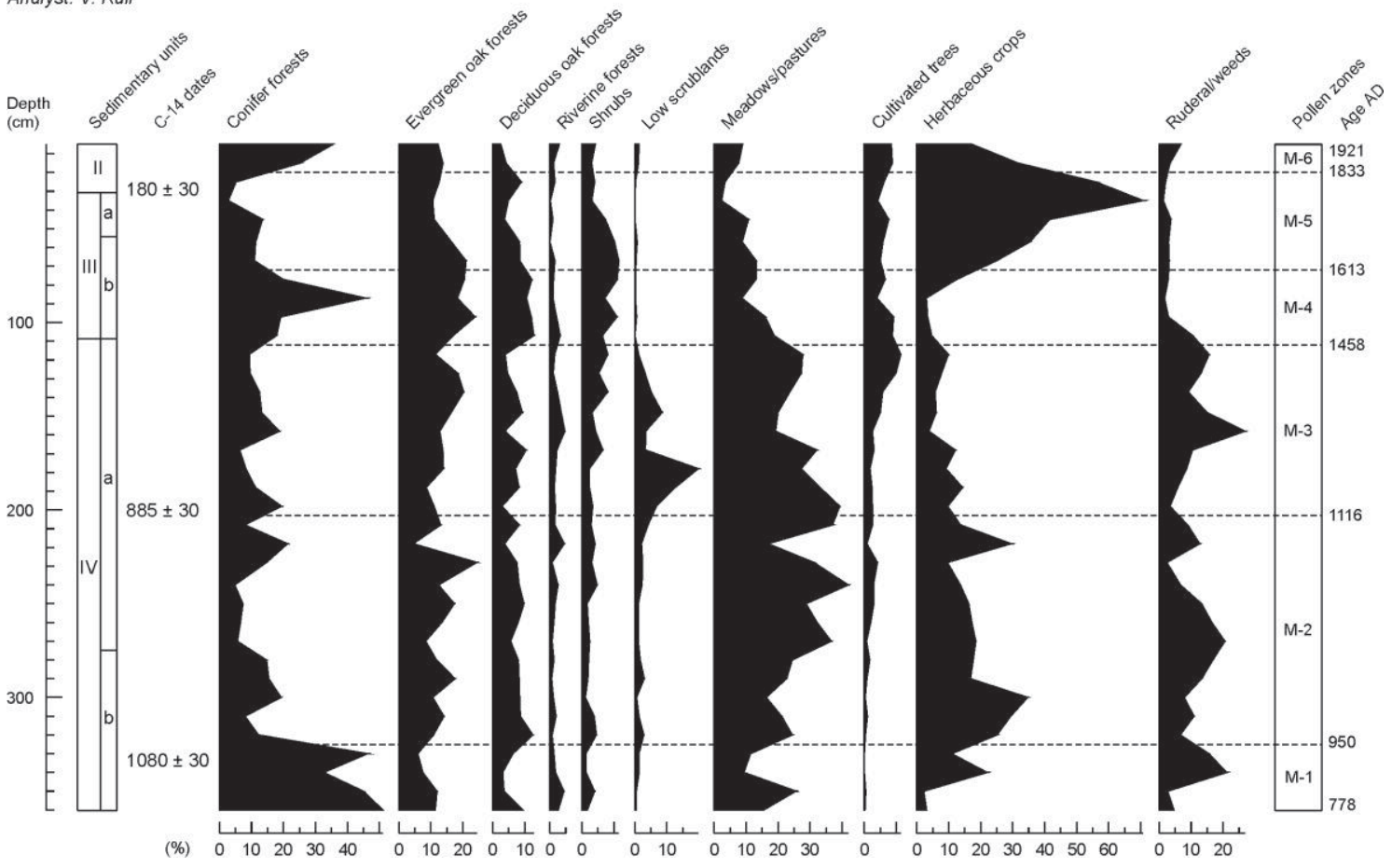

Figure 5

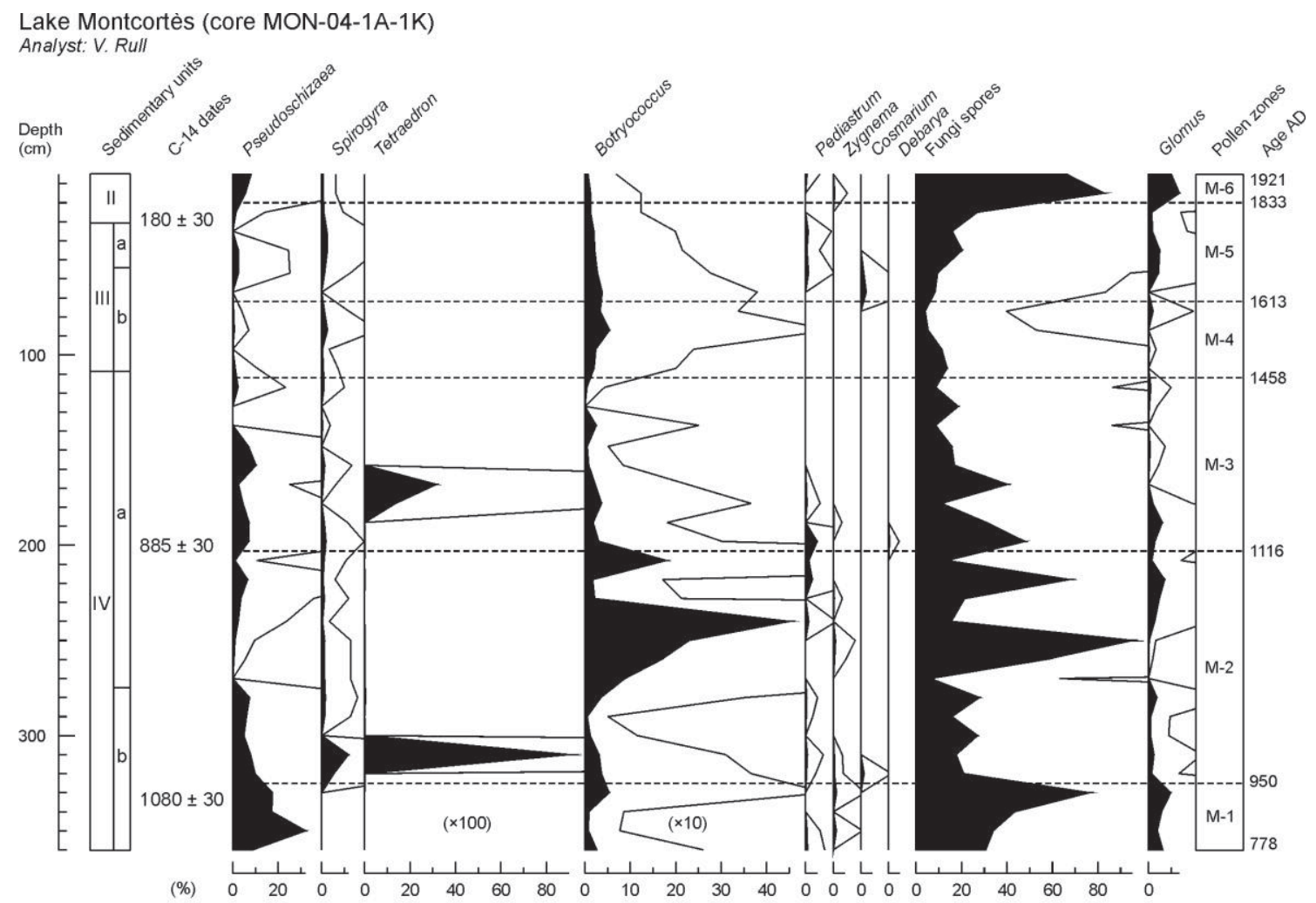

Figure 6 


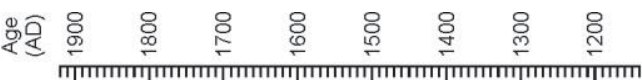
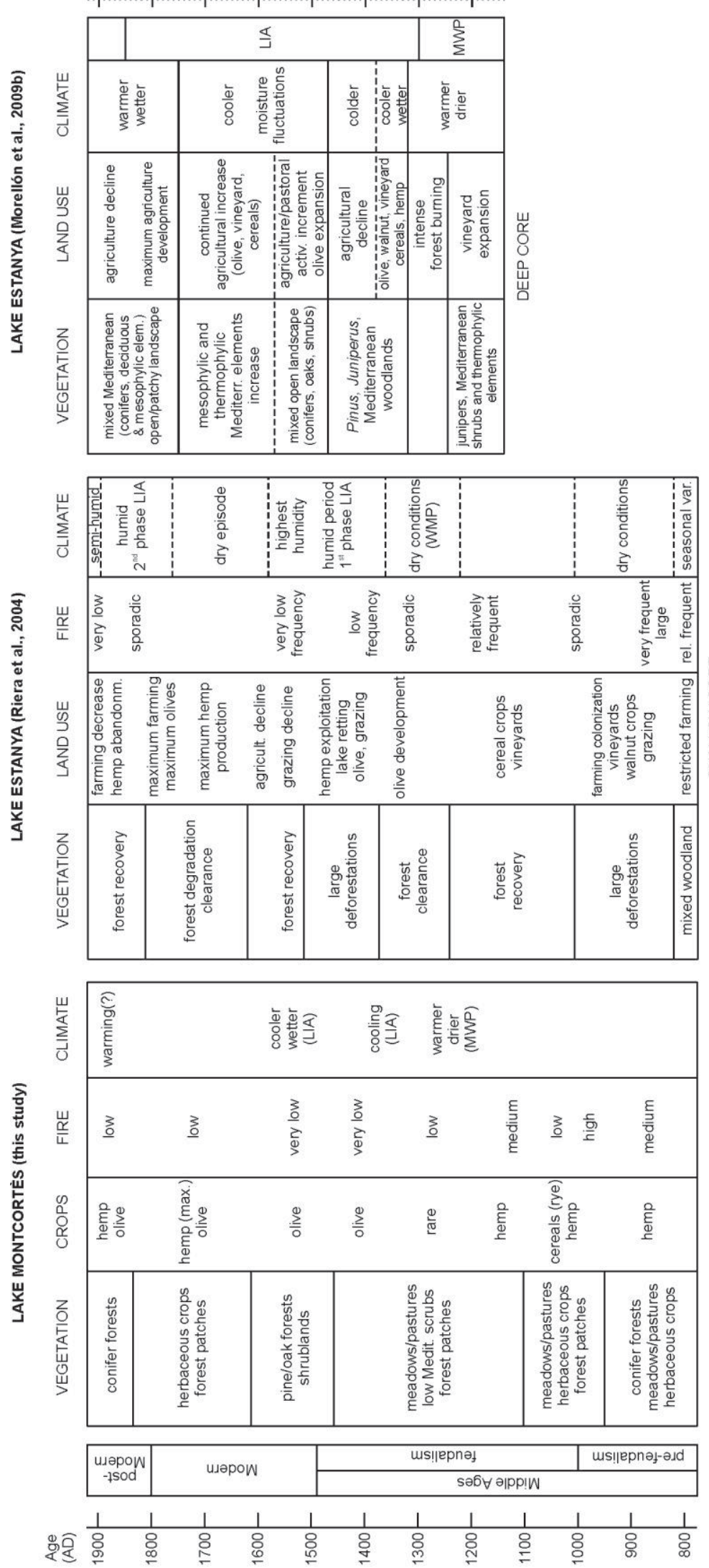

Figure 7 